\title{
Implementation of Teaching Factory in Improving the Competence of Vocational High School Students (SMK)
}

\author{
Een Rohaeni, Sutaryat Trisnamansyah, lim Wasliman, Supyan Sauri \\ Mahasiswa Pascasarjana Universitas Islam Nusantara, Bandung, Indonesia \\ Universitas Islam Nusantara, Bandung, Indonesia \\ Email: eensmkn13bdg@gmail.com, sutaryat0491@gmail.com, iimwasliman@uninus.ac.id, \\ uyunsupyan@upi.ac.id
}

\section{ARTICLE INFO}

Received

08 September 2021

Revision

13 September 2021

Approved

19 September 2021

Keywords:

Teaching Factory;

Student Competence;

SMK

\section{ABSTRACT}

The problem of low absorption of vocational graduates is allegedly due to a gap between the competencies possessed by students and the needs in the world of work. The participation of the industrial world and the world of work in the learning process in SMK is still low. The general objective of this study is to identify and analyze the implementation of the teaching factory in improving the competence of vocational students. The specific objectives of this study are to determine: (1) planning of the teaching factory; (2) teaching factory organization; (3) implementation of teaching factory; (4) evaluation of teaching factory implementation; (5) partnership in teaching factory implementation; (6) problems and solutions in the implementation of the teaching factory; (7) the results obtained from the implementation of the teaching factory. The theoretical basis uses the management theory of G.R. Terry, and the policy foundation is Presidential Instruction No. 6 of 2016 concerning Vocational Revitalization, where the teaching factory is one of the strategies for implementing Vocational Revitalization. The study used a qualitative approach with descriptive data collection techniques through interviews, observations, and documentation studies. Testing the validity of the data is done through triangulation of sources and triangulation of methods. The results of the study stated that: 1) the planning of the teaching factory in the fields of curriculum, infrastructure and financing had been carried out well, but in the field of human resources it was necessary to plan for teacher competency improvement; 2) the organization of the teaching factory has been carried out well, but it is necessary to make a SOP (Standard Operating Procedure) for activities; 3) The implementation of the teaching factory has been running well, supported by Jobsheet devices, but verification and validation activities are needed for the Jobsheets used; 4) The teaching factory evaluation activities have been going very well; 5) Partnerships in teaching factories have been going well for Lemon Juice, Herbs way and Yoghurt products, but it is necessary to increase the number of industrial partners for other types of products; 6) Solutions to the problem of improving teacher competence are handled through internal internships in teaching factory activities and becoming supervisors for Industrial Work Practices; 7) The results obtained from the teaching factory implementation activities can increase the competence of hard skills and $78.26 \%$ of students' soft skills.
How To Cite:

E-Issn:

Published By:
Rohaeni, E., et. al. (2021) Implementation of Teaching Factory In Improving The Competence of Vocational High School Students (SMK). Journal Of Social Science 2(5). https://doi.org/10.46799/jss.v2i5.220

2721-5202

Ridwan Institut 


\section{INTRODUCTION}

According to (Zuniarti \& Siswanto, 2013), good graduates who are able to compete with other nations can improve quality human resources. However, the quality of Vocational High School (SMK) graduates is still unresolved. Industry confidence in SMK graduates is getting lower, this can be seen from the lack of absorption of Vocational High School graduates in the world of work. On the other hand, this should not happen because according to Permendikbud No. 34 of 2018 concerning the National Standards for SMK/MAK Education states that SMK is part of the national education system which has the aim of vocational education, namely to produce skilled workers who can meet the demands of the business/industry world and can develop their potential in adopting and adapting. With the development of science, technology, and art. Vocational High Schools must be able to produce a competent workforce and be able to compete in the global era.

According to (Fikriawan, 2019) the indicator of community welfare is economic growth, because economic growth can give an overview of the effectiveness and development of the economy in a country in good condition (Alghofari \& Pujiyono, 2011). Meanwhile, graduates of Vocational High Schools (SMK) experienced the most unemployment reaching 8.49 percent. Elementary school graduates experienced unemployment reaching 2.64 percent, while junior high school graduates experienced an unemployment rate of 5.02 percent. High school graduates experienced an unemployment rate of 6.77 percent. Diploma and University graduates reached 6.76 percent and 5.73 percent, respectively. And in August 2020 the open unemployment rate in Indonesia increased from 5.23 percent to 7.07 percent or there was an increase in unemployment of 2.67 million (Agustina, 2020).

The policy of the Minister of Education and Culture in 2012 stated that the ratio of SMA and SMK was 51 to 49. By 2020, the number of SMKs will increase to $60 \%$. Currently, the growth of vocational schools has reached more than 14,000 vocational schools, exceeding the 2020 target of 7,500 vocational schools. With such a large number, learning must be well organized to ensure the quality of graduates.

The world of business, industry, and the world of work (DUDIKA) is an essential element in employment because it can absorb a workforce that is quite dominant for SMK graduates. However, DUDIKA's efforts to improve the quality of the learning process in SMK are still low. Therefore, there is a need for partnerships in activities to enhance the quality of learning and the existing Industrial Work Practices. This is in line with which states that "teaching factory learning becomes a learning concept in a real situation to bridge the competency gap between the knowledge provided by schools and industrial needs (Kuswantoro, 2014)." Learning through the teaching factory aims to develop character and work ethic (discipline, responsibility, honesty, cooperation, leadership, and others needed by DU/DI.

Efforts to improve the quality of graduates have been carried out but have not produced optimal results. Therefore, in 2016 the government issued Presidential Instruction No. 9 of 2016 concerning Vocational Revitalization. The revitalization of SMK is intended to increase the productivity and competitiveness of graduates. One of the vocational revitalization strategies is production-based learning (Teaching Factory).

However, this teaching and training have not been in line with technological advances. Modern concepts of training, industrial learning, and knowledge-giving schemes can improve innovation performance (Mavrikios, Sipsas, Smparounis, Rentzos, \& Chryssolouris, 2017).

The teaching factory is a governmentdeveloped program to provide teachers and students with market-oriented practical work. According to (Wijaya 2013) states that the Teaching Factory program approach is a combination of Competency-Based Training (CBT) learning approaches where training is based on the work done by students in the workplace and Production Based Training (PBT) is a skill and skill learning process designed and implemented based on actual job procedures and standards to produce goods and services according to market demands.

According to (Nurtanto, Ramdani, \& Nurhaji, 2017), the purpose of the Teaching 
factory is to change that and teach students more than what is in the book. Not only do students practice the "soft skills in the Learning factory, such as teamwork and interpersonal communication skills, but they also get the necessary hands-on experience and future job training. Learning Factory participants learn how to define a problem, build a prototype, write a business proposal, and make a presentation about their solution. The students learn critical skills such as meeting deadlines and expectations on multidisciplinary teams and using varied talents in the process.

To implement the teaching factory properly, good management of the teaching factory is needed. According to George $\mathrm{R}$ Terry (Mukhtar Latif, 2018), The definition of management is:: 'Management is a distinct process consisting of planning, organizing, actuating and controlling; utilizing both science and art and followed to accomplish ore -determine objectives.' Therefore, the implementation of the teaching factory in this study describes the management components, namely planning, organizing, implementing, and monitoring/evaluation, where the output of the implementation of the teaching factory is related to learning theory according to Pritchard, which states that learning is a process of changing behavior as a result of experience. Or experiment.

\section{METHOD}

The research method used is a descriptive method with a quantitative approach. This approach refers to the research objective, namely to find out and analyze the implementation of the teaching factory in improving the competence of vocational students. The specific purposes of this research are to find out:

a. teaching factory planning;

b. organizing teaching factory;

c. implementation of teaching factory;

d. evaluation of teaching factory implementation;

e. partnership in teaching factory implementation;

f. problems and solutions in the performance of the teaching factory;

g. the results obtained from the implementation of the teaching factory.
This research was conducted at SMK Negeri 1 Cibadak, Sukabumi district and SMK Negeri 1 Pacet, Cianjur district, West Java province. Data collection techniques through interviews, observation, and documentation studies. Testing the validity of the data is carried out through source triangulation and technical triangulation tests.

\section{RESULTS AND DISCUSSION}

\section{A. Research result}

\section{a. Teaching factory planning}

Teaching Factory Model is a concept of learning in production/ service-based vocational high schools that refers to standards and procedures applicable in the industry (DU-DI) and is carried out in an atmosphere as is the industry's case. To be competent, the concept of teaching factory learning applies an action-oriented learning approach in a productiontechnology learning environment (Al-Moyed et al., 2019). Therefore, teaching factory-oriented learning combines existing learning, namely Competency-Based Training and Production Based Training. This means that a process of expertise or skill is designed and implemented based on actual procedures and standard operating procedures to produce products in line with market/ consumer demands (Wahjusaputri, Marlina, \& Latifah, 2020).

Teaching factory planning includes curriculum planning, human resources, infrastructure, and financing. Curriculum planning is carried out at the beginning of each lesson through IHT (In-house training) activities. Every year make product innovations, add product types and make production targets for each product. Establish procedures for production, then perform KD selection on the syllabus from the start, process, results, and product reporting. Next, the teacher prepares learning tools consisting of the syllabus analysis, lesson plans, and job sheets.

Although Industry 4.0 has begun being integrated into manufacturing, much has to be achieved in educating and attracting young talent in the 
industry. It aims to bridge the gap between the implementation of educational organizations focused on this area. This plan focuses on developing contemporary teaching (Mourtzis, Vlachou, Dimitrakopoulos, \& Zogopoulos, 2018).

The steps taken in the preparation of infrastructure facilities are 1) Analysis of the problems that will be carried out by each department; 2) Inventory of equipment that supports each department; 3) Teaching factory support capacity. Schools submit infrastructure facilities to the government and collaborate with other parties, such as industry, to make it easier to prepare practical learning infrastructure facilities in vocational schools (Alan Pritchard, 2009).

In the last decade, the concept of Teaching Factory has gained significant interest, especially in the U.S., resulting in many educational or business pilot activities. Many educational institutions have tried to bring their educational practices closer to the industrial (Rentzos, Doukas, Mavrikios, Mourtzis, \& Chryssolouris, 2014).

Planning for human resources, especially educators (teachers), is carried out to support the successful implementation of the teaching factory. Teachers are included in industrial internships, P4TK VEDCA Cianjur Regency training, and competency assessor training from BNSP. Both schools already have a competency certificate from BNSP, which has reached $80 \%$ of vocational teachers. At the same time, $20 \%$ are honorary teachers who have participated in internships at P4TK VEDCA Cianjur Regency but have not carried out competency training and competency tests from BNSP.

Planning in financing to increase teaching factory activities is carried out during the preparation of the RKAS, originating from central or regional government assistance and public funds.

\section{b. Teaching factory organization}

At this stage, the school makes a personal determination by the abilities and tasks that have been carried out. The school designs an organizational structure to manage the teaching factory by private person who can work professionally. This is because the Principal has assigned a teaching factory management team equipped with a job description.

Teaching concepts and learning tasks can be designed based on theory, industrial prototyping, or research results. The educational arrangements achieved can be implemented in two industrial and miniature cases (Engelhardt-Nowitzki, Aburaia, Otrebski, Rauer, \& Orsolits, 2020).

\section{c. Implementation of the teaching} factory

The implementation of the teaching factory is divided into 3 (three) models. Namely, students study in the industry in 2 weeks, learn at school by carrying out jobs from industry, and produce at school and market their products. The teaching factory activity scheduling system is a block and learning system with a collaborative approach between subjects. C (vocational) subjects collaborate with $A$ and $B$ subjects, or between $C$ content subjects, namely PKK (Creative Entrepreneurship Products) or Food Safety subjects.

Other operational processes, such as maintenance, closely related to effective production systems, can benefit from the same advantages of an action-oriented learning environment. It is equally essential in developing a maintenance plan that training must go beyond theoretical knowledge to real-world contexts. One of the challenges with creating a maintenance plan is to determine the failure behavior of a system. This is usually done by studying historical failure data, which is rarely available in a learning environment. Furthermore, the development of the maintenance plan involves an interdisciplinary team during the development process. Therefore, the training environment must expose students to the dynamics involved with forming part of a 
multidisciplinary team(Jooste et al., 2020).

d. Evaluation of Teaching Factory Implementation

Evaluation of teaching factory implementation includes evaluation of activities and assessment of learning. Assessment of the success of teaching factory activities is carried out every year. Reporting on learning outcomes has been carried out with a suitable mechanism every 6 (six) months.

The assessment of teaching factory activities uses the LSP (Professional Certification Institute) BNSP competency test assessment instrument. It uses the assessment instrument on the job sheet and the National Vocational Vocational Practice exam assessment system.

e. Partnership in Teaching Factory Implementation

The partnership starts with the formulation and analysis of $K D$, analysis of the equipment needed, structuring the required practice space, validating work procedures that will be implemented, and fostering student character. The school's partnership with DUDIKA has been well maintained, as seen from the continuity of the Collaboration with DUDIKA since its inception.

f. Problems and Solutions in Teaching Factory Implementation

The teaching factory activities as a whole ran smoothly, without any significant problems. If a problem occurs, then the problem can be adequately resolved. The experienced issues have become a concern for the school to control production activities to run smoothly and successfully teaching factory learning.

g. Results of Teaching Factory Implementation.

The results of the assessment carried out through the skill competency test held by LSP-P1 showed that the students were declared competent, and the results of the Vocational School Exams for class XII students of APHP skill competence at SMKN 1 Cibadak, Sukabumi Regency with 35 students in the 2020-2021 academic year showed an average result. A good score is 86.14 , while for students of SMKN 1 Pacet with 53 people, the average result is a good score of 83.5. The soft skill aspect achieved $78,26 \%$ of all desired aspects. And high absorption above $76 \%$ and absorbed abroad, namely Japan, Germany, and Taiwan.

\section{B. Discussion}

\section{a. Teaching Factory Planning}

The teaching factory planning is contained in the school activity plan (RKS) and the Medium-Term Work Plan (RKJM) so that the development plan becomes clear and its achievements are directed. The steps that must be taken in planning the Teaching Factory include planning for the type of product to be produced, other supporting facilities such as the availability of equipment and materials, standardized procedures, and a standardized space with the industry. Implementation of syllabus analysis, KI - KD (Core Competencies - Basic Competencies), a collaboration between subjects, breakdown of equipment and practice materials, human resources, and external resources (partnerships) analysis.

The Teaching Factory concept is based on the knowledge triangle notion. The idea of the Teaching Factory has its origins in the medical sciences discipline and

specifically, in the paradigm of the teaching hospitals, namely the medical schools operating in parallel with hospitals (Chryssolouris, Mavrikios, \& Rentzos, 2016).

It aims to incorporate the learning and working environment from which realistic and relevant learning experiences arise. The concept of the Teaching Factory has its origins in the medical sciences discipline and, specifically, in the paradigm of the teaching hospitals, namely the medical schools, operating in parallel with hospitals. It aims to incorporate the learning and working environment from which realistic and relevant learning experiences arise (Mavrikios, Georgoulias, \& Chryssolouris, 2018). 
Planning in the field of infrastructure is a process to fulfill learning needs both in theory and practice and improve the quality of learning. Based on Permendikbud No 34 of 2018 concerning National Standards, Annex VI, namely Standards for Infrastructure related to Practice Rooms and Teaching Factory Development Guidelines, Directorate of Vocational Development, Ministry of Education and Culture.

Human resource planning for educators refers to Law Number 14 of 2005 concerning Teachers and Lecturers in article 1 paragraph 1 , which states that teachers are professional educators with the main task of educating, teaching, guiding, directing, training, assessing, and evaluating students in children's education. Early childhood through formal education, primary education, and secondary education. As professionals, the position of teachers is aimed at implementing the national education system and realizing the goals of national education, namely the development of the potential of students to become human beings who believe and are devoted to God Almighty, have a noble character, are healthy, knowledgeable, capable, creative, independent, and become democratic and responsible citizens. Article 8 of the law states that teachers must have academic qualifications, competencies, educator certificates, physical and mental health, and national education goals.

In Permendikbud No 34 of 2018 concerning National Education Standards in Appendix $\mathrm{V}$ concerning Standards for Educators and Education Personnel, it is stated that the planning for the development of educators and education personnel includes increasing academic qualifications and increasing competence both educational and professional competence. One of the professional competencies of teachers contained in the Permendikbud is mastering the material broadly and deeply. Therefore, to fulfill the ability to master the material widely and deeply for vocational teachers, it is proven by having an educator certificate, a certificate of competence. Teachers can become assessors in the Expertise Competency Test (UKK) at the Competency Certification Institute if they have 2 (two) types of certificates, namely assessor certificates and competency certificates (technical). Competency assessor training is carried out by the National Competency Certification Agency (BNSP). The research findings at both locations obtained data that the percentage of vocational teachers who already have a certificate of competence is $80 \%$. With the assets of teachers who already have competency certificates, the APHP Skills Competency Test activities at LSP $\mathrm{P}-1$ in both research locations have been very well implemented. However, to get competent teachers in their fields, it is necessary to conduct a competency training program by the subjects they teach to obtain a competency certificate from BNSP.

The development of teaching factories in both schools uses BOS funds from the central government, namely from the allocation of activities to increase skill competence and maintenance of school infrastructure, namely in financing the purchase of materials and equipment that are not investment equipment. Therefore, the government's cooperation, in this case, the Ministry of Education and Culture in collaboration with the German government in the form of vocational equipment assistance for Vocational High Schools in Indonesia, has been very helpful in implementing the teaching factory since the service was rolled out in 2013 until now.

\section{b. Teaching Factory Organization}

The organizational structure that has been created has followed the provisions in the Teaching Factory implementation guide from the Directorate of Vocational Development of the Ministry of Education and Culture of the Republic of Indonesia. It has the same hierarchy where the Principal is assisted by the Deputy Principal and the Head of expertise 
competence. Each of which the Head of expertise competence oversees production units managed by subject teachers and technicians.

According to Terry (Mukhtar Latif, 2018), 'organizing is a way to gather people and place them according to their abilities and expertise in the work that has been planned.' The organization in both schools has been carried out with the same principle, namely placing people based on their abilities and expertise.

\section{c. Implementation of Teaching} Factory

The implementation of the teaching factory is carried out through collaboration in the performance of learning content for groups $A$ and $B$ and group $C$ (vocational content). This activity is carried out with a block system. According to the Minister of Education and Culture No. 34 of 2018 concerning National Education Standards in Appendix III concerning Process Standards, it states that block system learning is an arrangement of learning implementation that allows the incorporation of several competencies in a complete and meaningful way to achieve learning objectives that are held in specific time blocks according to the characteristics of the competencies. It was further explained that the block system learning could be done in SMK/MAK, industry, or alternately in industry and SMK/MAK according to the time, resources, equipment, and materials determined. The two schools did this by the agreement between the industry and the school; both the number of students sent and the length of learning in the sector ranged from 2 weeks to 1 month. The implementation of the teaching factory with a pattern of collaboration with industry has so far had other impacts, such as the student's experience of working with a natural work climate. Control is carried out from the design stage, implementation to the final result to carry out the work by predetermined quality standards. The performance of power is carried out by teachers accompanied by instructors from the industry.

\section{d. Teaching Factory Evaluation}

A suitable mechanism has evaluated the implementation of the teaching factory in both SMKs. The Principal has an outstanding commitment and responsibility in maintaining the continuity of teaching factory activities. The Principal analyzes reporting results. The evaluation system and follow-up evaluations are then carried out by the Principal the following year for the development of the teaching factory

According to Permendiksud No. 34 of 2018 concerning National Education Standards, Annex III of Process Standards, in practical learning, teachers/instructors conduct assessments according to the characteristics of skills contained in the content standards and syllabus after students perform skills without guidance. Student competency assessment activities are intended to determine the extent of students' competencies after the learning process. The results of the learning evaluation carried out through the Skills Competency Test managed by LSP P-1 (Professional Certification Institution) students of APHP expertise competence in both schools were $100 \%$ declared competent.

\section{e. Teaching Factory Partnership}

Partnerships with the industry are built through industry trust in the quality of students or alumni. When students meet industry criteria and perform well during on-the-job or work practices, the industry has since recognized the school. The involvement of industry in various school activities will result in a harmonious relationship and mutual support for the programs of both parties.

According to the teaching factory development guidebook, the Directorate of Vocational states that some of the benefits in implementing cooperation with industry/services include:

a. It knows the type and quality of products or services with good 
prospects and meets consumers' requirements and needs.

b. It knows the procedures and ways of working in producing products or carrying out services.

c. It knows the conditions of the workspace by work requirements which include: work safety, work requirements, work environment.

d. It knows the possibility of industrial/work waste and the procedures for handling it.

e. Knowing the skills that workers need to have by industry needs, which include: attitude skills/soft skills that are specific to the type of industry, for example, obeying SOPs/regulations, being clean, disciplined, punctual, ability to focus on work and hard skills, work attitude for instance resistance to work while standing, body resistance in certain positions; work appearance, among others, use, tidiness of the completeness of work uniforms, polite

f. Performance evaluation not only focuses on the mastery of work skills but also on the attitudes possessed by workers and the knowledge that supports the implementation of workers.

g. Type and level of technology used.

h. Opportunity to transfer technology, skills through apprenticeship/work in the industry.

i. Obtain information about the possibility of obtaining guest teachers from instructors or senior workers from the industry.

As for the industry, the benefits that can be obtained include:

a. Obtain workers who have the attitudes, knowledge, and skills by their requirements and needs to hire immediately.

b. We are reducing the costs involved in conducting initial training for workers.

c. Get workers who already know the procedures and work procedures in the industry.

d. Get workers who have an attitude and work ethic that match the needs of the industry.
The pattern of cooperation between drives in the implementation of teaching factories is that students practice in companies/industries for a time agreed upon by the industry and the school.

From the research results, the two schools have succeeded in building partnerships related to teaching factories. It can be seen from the high absorption rate in the world of work. The trust is given to 45 (forty-five) students working in one industry and students working internships abroad in both schools. This shows that the graduates meet the criteria required by the industry both domestically and abroad. Through the teaching factory, the two research locations have become excellent and outstanding schools. From the partnership aspect, it can be concluded that the two research locations have been very good at implementing partnerships in various stages of implementing the teaching factory.

f. Problems and solutions in teaching factory implementation

The problem of the number of teachers that is still lacking is overcome by recruiting honorary teachers. Honorary teachers who join are given a competency improvement program through training activities carried out at P4TK VEDCA Cianjur. The implementation of competency certification is still being carried out in stages because $20 \%$ of teachers in both schools have not received a competency certificate from BNSP. However, with the application of crossassessment where teachers who provide practical guidance are not allowed to make assessments in the production field they are mentored, it is a good step in terms of efforts to increase teacher abilities and encourage teachers to have competence in both knowledge and skills in the field of production that they are not mentored.

Learning facilities in the teaching factory activities did not experience problems because they had been handled directly. The condition of 
practical infrastructure has exceeded the standards of Permendikbud No 34 of 2018 Appendix III on Standards for Infrastructure. The Teaching factory development guidelines from the Directorate of Vocational regarding the criteria for practice rooms.

Implementing the productionbased teaching factory has consequences because implementing the teaching factory requires mental readiness for both students and parents. Applying the teaching factory that is close to the work pattern in the industry requires a good understanding of the students and their parents. Student character needs to be formed so that students are accustomed to having attitudes and behaviors that are faithful and devoted to God Almighty, honest, disciplined, responsible, and can work together in a workgroup system. The formation of this character requires cooperation between family education and education in schools., SMK, in applying the Teaching Factory concept, should have a permanent partnership relationship with the industry. Vocational schools implement teaching factories to synergize with industry for all stages of learning at the planning, implementation, assessment, certification, and evaluation stages of learning outcomes. No significant problems were found from the partnership aspect at the two research locations, which harmed both parties. The relationship that has been established continues to run harmoniously by carrying out each other's rights and obligations according to the agreement.

\section{g. Teaching Factory Implementation Results}

Students and other school members feel the results obtained from teaching factory learning. Teaching factory learning encourages teachers to be more creative, innovative, and productive. With production-based education, students acquire knowledge, skills, and attitudes by Graduate competency and industry standards. These competencies include Hard skill competencies and soft skill competencies. The complex skill competencies obtained are:

a) Have good vocational skills

Students get an excellent average score on the Vocational Competency Test, which is above the value of 83.5. Students are declared to be $100 \%$ competent in the LSP P-1 competency test activity and get a competency certificate.

b) Focus on work

Students carry out practical activities with task orientation to produce products with criteria that have been set both by industry and by subject teachers. Failure during production is students' responsibility so that students have to re-unite with other groups on the following schedule.

c) Realizing the curriculum content factually

Practical learning with the teaching factory model provides real experience to students about the achievement of KD in the curriculum and the application of $K D$ in a production process.

The teacher monitors soft Skill competencies through an assessment of work attitudes in the learning process. The gentle skill aspect to be achieved is stated in the Job sheet. Characteristics of soft skills obtained by students from the two schools are:

1) Obedient to worship

Students pray before and after the lesson, carry out worship during practice breaks, protect the environment.

2) Honest

Students communicate the production results honestly, do not exchange other people's workpieces, do not hide damaged workpieces, report damage to the tools used, do not provide false information both verbally and in writing, do not contain elements of plagiarism in report writing.

3) Discipline

It complies with work safety
using


maintenance/lubrication before and after using the machine/tool, using the device according to its standard function. Do not leave the laboratory/workplace without the permission of the teacher/instructor.

4) Responsibility

Students complete all their assignments and make reports on production results.

5) Cooperation

Students are formed in groups in a production process so that cooperation between group members is included.

6) Instilling an entrepreneurial spirit

In teaching factory activities in schools, students market the products they make and report the outcomes. In general, $100 \%$ of the products produced can be sold, with the average achievement of sales to the community reaching $80 \%$ and sales to their families reaching $20 \%$.

7) Independent

Do not have work dependence on others, keep a practicum journal, prepare equipment and practice materials needed, carry out sanitation in the application of personal hygiene

8) Accuracy

Accuracy in analyzing the quality of raw materials, weighing raw materials, and handling raw materials.

9) Accuracy

Carry out all the tests required in the procedure and be careful in observing the production process,

10) Punctuality

Completing the work with a measured time, the spare time for completion/lack of time to complete the job will reduce value; on the other hand, if the work is on time or completed before the set time, it will get an additional discount.

11) Easily adaptable

Students are easy to adapt during practice because students are used to industrial work standards, the target results achieved, accustomed to interpersonal communication, accustomed to applying personal hygiene, accustomed to working with behavior in laboratories, and aspects of industrial work culture.

12) Get used to the behavior in the laboratory

Use personal protective equipment, use established practice clothes, do not take actions/deeds that harm others, maintain a clean work environment, and support equipment.

13) Manners

Do not speak dirty to fellow students, instructors, teachers, and staff; do not make noise. Communicate using the language of instruction.

14) Hard work

Have fighting spirit and work spirit, don't talk or joke when working with tools or during simulation practice, weighty when carrying out the procedure.

15) Able to interact both vertically and horizontally

Get along well and politely with fellow students, teachers, instructors, and other school members, the ability to respect ideas, suggestions, and opinions of friends

16) Obey

Make reports according to the format (title, objectives, material tools, work steps, discussions, and conclusions). Students follow the rules in the laboratory.

17) Creative

They are designing product variations, designing product packaging, providing ideas in the production process.

18) Confident

We are presenting the results/results of work, marketing the products, answering questions during group discussions, and communicating verbally during group discussions. 


\section{CONCLUSION}

a) Teaching factory planning in the field of curriculum, infrastructure, and financing has been carried out well, but in the field of $H R$, it is necessary to plan for teacher competency improvement, $b$ ) The organization of the teaching factory has been carried out well, but it is necessary to make an SOP (Standard Operating Procedure) for activities,c) The implementation of the teaching factory has been going well, supported by the Job sheet device, but it is necessary to carry out verification and validation activities on the Job sheet used,d) The teaching factory evaluation activity has gone very well by implementing the Profession Certification System Expertise Competency Test,e) The partnership in the teaching factory has been going well for Lemon Juice, Herbs way, and Yoghurt products. Still, it is necessary to increase the number of industrial partners for other types of products.f) The solution to the problem of increasing teacher competence is handled through internal internships in teaching factory activities and becoming a supervisor for Industrial Work Practices,g) The results obtained from teaching factory activities can increase the competence of hard skills and $78.26 \%$ of students' soft skills.

\section{REFERENCES}

Agustina, Dwi. (2020). Analisis Pengaruh Tingkat Pengangguran Terbuka Dan Indeks Pembangunan Manusia Terhadap Kemiskinan Di Provinsi Jawa Tengah. Jurnal Saintika Unpam: Jurnal Sains Dan Matematika Unpam, 3(1), 81-88.Google Scholar

Al-Moyed, Hanan, Cepeda, Andreia P., Jung, Sangyong, Moser, Tobias, Kügler, Sebastian, \& Reisinger, Ellen. (2019). A Dual-Aav Approach Restores Fast Exocytosis And Partially Rescues Auditory Function In Deaf Otoferlin Knock-Out Mice. Embo Molecular Medicine, 11(1), E9396. Google Scholar

Alghofari, Farid, \& Pujiyono, Arif. (2011). Analisis Tingkat Pengangguran Di Indonesia Tahun 1980-2007. Universitas Diponegoro. Google Scholar

Chryssolouris, G., Mavrikios, D., \& Rentzos, L.
(2016). The Teaching Factory: A Manufacturing Education Paradigm. Procedia Cirp, 57, 44-48. Https://Doi.Org/10.1016/J.Procir.2016.1 1.009. Google Scholar

Engelhardt-Nowitzki, Corinna, Aburaia, Mohamed, Otrebski, Richard, Rauer, Johannes, \& Orsolits, Horst. (2020). Research-Based Teaching In Digital Manufacturing And Robotics - The Digital Factory At The Uas Technikum Wien As A Case Example. Procedia Manufacturing, 45, 164-170. Https://Doi.Org/10.1016/J.Promfg.2020. 04.089. Google Scholar

Fikriawan, Suad. (2019). Dinamika Zakat Dalam Tinjauan Sejarah Keindonesiaan: Kajian Positifikasi Dan Implikasinya Bagi Ekonomi Umat. Al-Manhaj: Jurnal Hukum Dan Pranata Sosial Islam, 1(1), 73-92. Google Scholar

Jooste, Johannes L., Louw, Louis, Leipzig, Konrad Von, Conradie, Pieter D. F., Asekun, Olabanji O., Lucke, Dominik, \& Hagedorn-Hansen, Devon. (2020). Teaching Maintenance Plan Development In A Learning Factory Environment. Procedia Manufacturing, 45, 379-385. Https://Doi.Org/10.1016/J.Promfg.2020. 04.040 Google Scholar

Kuswantoro, Agung. (2014). Teaching Factory: Rencana Dan Nilai Entrepreneurship. Yogyakarta: Graha Ilmu. Google Scholar

Mavrikios, Dimitris, Georgoulias, Konstantinos, \& Chryssolouris, George. (2018). The Teaching Factory Paradigm: Developments And Outlook. Procedia Manufacturing, 23(2017), 1-6. Https://Doi.Org/10.1016/J.Promfg.2018. 04.029 Google Scholar

Mavrikios, Dimitris, Sipsas, Konstantinos, Smparounis, Konstantinos, Rentzos, Loukas, \& Chryssolouris, George. (2017). A Web-Based Application For Classifying Teaching And Learning Factories. Procedia Manufacturing, 9, 222-228. 
Https://Doi.Org/10.1016/J.Promfg.2017. 04.002 Google Scholar

Mourtzis, D., Vlachou, E., Dimitrakopoulos, G., \& Zogopoulos, V. (2018). CyberPhysical Systems And Education 4.0 The Teaching Factory 4.0 Concept. Procedia Manufacturing, 23(2017), 129134.

Https://Doi.Org/10.1016/J.Promfg.2018. 04.005 Google Scholar

Mukhtar Latif, M. Pd. (2018). Teori Manajemen Pendidikan: Edisi Pertama. Prenada Media. Google Scholar

Nurtanto, Muhammad, Ramdani, Sulaeman Deni, \& Nurhaji, Soffan. (2017). Pengembangan Model Teaching Factory Di Sekolah Kejuruan. Prosiding Seminar Nasional Pendidikan Fkip, 1(2). Google Scholar

Rentzos, L., Doukas, M., Mavrikios, D., Mourtzis, D., \& Chryssolouris, G. (2014). Integrating Manufacturing Education With Industrial Practice Using Teaching
Factory Paradigm: A Construction Equipment Application. Procedia Cirp, 17, 189-194. Https://Doi.Org/10.1016/J.Procir.2014.0 1.126. Google Scholar

Wahjusaputri, Sintha, Marlina, Elin, \& Latifah, Siti. (2020). Developing The Teaching Factory Learning Media In A Public Vocational High School. Jurnal Pendidikan Vokasi, 101), 69-79. Https://Doi.Org/10.21831/Jpv.V10i1.302 22. Google Scholar

Wijaya, M. Burhan R. (2013). Model Pengelolaan Teaching Factory Sekolah Menengah Kejuruan. Jurnal Penelitian Pendidikan, 30(2). Google Scholar

Zuniarti, Zuniarti, \& Siswanto, Budi Tri. (2013). Pengaruh Motivasi Belajar, Kinerja Intensitas Pembimbingan Prakerin Terhadap Kesiapan Kerja Siswa Smk Pariwisata Diy. Jurnal Pendidikan Vokasi, 3(3). Google Scholar

\section{Copyright holder:}

Een Rohaeni, Sutaryat Trisnamansyah, Iim Wasliman (2021)

First publication right:

Journal of Social Science

This article is licensed under:

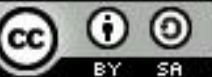

